\title{
9
}

\section{The Stock-flow Consistent Approach with Active Financial Markets*}

\author{
Jan Toporowski and Jo Michell
}

\subsection{Introduction}

Wynne Godley is best known for his insightful forecasting using stockflow consistent models. His insistence that economic stocks and flows should be consistently laid out was also, if less obviously, an insistence that all economic variables are interrelated. Accordingly, production could not be carried out without distributional implications. More importantly, for the theory of a modern credit economy, the financial flows that arise in the process of production and exchange have to be integrated into the model of the economy at large.

Stock-flow consistency has clear implications for economic forecasting. However, it also has very critical implications for econometrics, in its modern sense of deriving theory from statistical data. For, if statistics are themselves the product of a stock-flow consistent taxonomy, then there are no independent variables, but all variables are interdependent (Godley and Lavoie, 2007; Toporowski, 2001). One interpretation of this interdependence could be the New Classical view that an economy is at all times more or less in successive states of general equilibrium, or shifting between them under the impact of various 'shocks', usually identified with hindsight. In such a situation, forecasting is only possible on the basis of probability distributions derived from the frequency distribution of past 'shocks.'

We argue here that a disequilibrium interpretation is also possible. This could be a Wicksellian cumulative process derived from nonequilibrium transactions in markets over real time. Two situations may

* This chapter draws on discussions that we have had with Jago Penrose and Marc Lavoie. The authors take full responsibility for all remaining errors. 
give rise to such a cumulative process. One is capital market inflation, in which the rising values of financial assets give rise to wealth effects behind which lie bank disintermediation and overcapitalization of large corporate businesses. The other situation is overcapitalization itself, a form of liquidity preference in which non-financial firms enter into the business of financial intermediation.

This chapter aims to illustrate the problems of capturing the subtleties of changes in financial structure and firm behavior in a pure stock-flow consistent model, through a discussion of the issues surrounding firms' decisions in financially developed capitalist systems, and in particular, overcapitalization and liquidity management. These concepts emerge from the work of Kalecki, Steindl and Minsky.

By considering these ideas in the context of the constraint of stockflow consistency, the problems of incorporating financial development, cyclical behavior and heterogeneous agents into a formal stock-flow model are illustrated. Insights are also gained into Kaleckian ideas on the relationship between investment and profits, and, in particular, the financial counterparts to the identities linking these real-sector flows. The exercise also serves to highlight some of the logical implications of firm overcapitalization and liquidity management that emerge when considered in a stock-flow consistent framework.

\subsection{Simple 'classical' system}

The starting point for the discussion will be a simple system in which firms borrow in order to invest in new capital, all saving takes place in the household sector, and the only form of financial assets are bank deposits and loans. This system is shown in Table 9.1.

Following Godley and Lavoie (2007), the table shows a 'transactions flow matrix' - a specification of all the potential real and financial flows in the model economy. This is essentially an abstract representation of the accounts published as the 'flow of funds' in many countries. In the matrix, positive values represent sources of funds while negative values represent uses of funds. For each sector, total sources and uses of funds must be equal, implying that columns must sum to zero. Likewise, the constraint that all flows must 'go somewhere' implies that all rows must also sum to zero -- all liabilities issued must appear as assets elsewhere in the system, and all spending in the real sector must be matched by expenditure. The firm and bank sectors are split into a current account and a capital account. This allows for the explicit inclusion into the matrix of profits and investment flows. 


\section{PROOF}

Jan Toporowski and Jo Michell

175

Table 9.1 'Classical' case: investment funded by bank loans - no profits in firm sector

\begin{tabular}{|c|c|c|c|c|c|c|}
\hline & Households & $\begin{array}{l}\text { Firms } \\
\text { (cur) }\end{array}$ & $\begin{array}{l}\text { Firms } \\
\text { (cap) }\end{array}$ & $\begin{array}{l}\text { Banks } \\
\text { (cur) }\end{array}$ & $\begin{array}{l}\text { Banks } \\
\text { (cur) }\end{array}$ & Total \\
\hline Consumption & $-C$ & $+C$ & & & & 0 \\
\hline Investment & & $+I$ & $-I$ & & & 0 \\
\hline GDP & & {$[Y]$} & & & & \\
\hline Wages & $+W$ & $-W$ & & & & 0 \\
\hline Firm Profits & & & & & & 0 \\
\hline Bank Profits & & & & $-S_{b}$ & $+S_{b}$ & 0 \\
\hline Deposit interest & $+r_{D} \cdot D_{(-1)}$ & & & $-r_{D} \cdot D_{(-1)}$ & & 0 \\
\hline Loan interest & & $-r_{L} \cdot L_{(-1)}$ & & $+r_{L} \cdot L_{(-1)}$ & & 0 \\
\hline Net fin. balance & {$\left[S_{h}\right]$} & [0] & {$[-I]$} & {$[0]$} & {$\left[S_{b}\right]$} & 0 \\
\hline Chge in Deposits & $-\Delta D$ & & & & $+\Delta D$ & 0 \\
\hline Chge in Loans & & & $+\Delta L$ & & $-\Delta L$ & 0 \\
\hline Total & 0 & 0 & 0 & 0 & 0 & 0 \\
\hline
\end{tabular}

It should be stressed that stock-flow consistent models, in the form presented by Godley and Lavoie, contain two broad 'layers' of constraints that define the structure of the model. The first such layer is that imposed by the system of accounting matrices that defines the configuration of stocks, flows, and - in more complex models - asset revaluations that define the broad structure of the model, particularly the financial system. As this set of constraints takes the form of a set of pure of accounting relationships, no assumptions about the causality of the system can be included in, or inferred from, a model of this type. Assumptions on the causality underlying the functioning of the economic system are then introduced by the careful construction of a set of behavioral equations that fit together in such a way as to ensure that the stock-flow constraints cannot be breached. It is thus the case that a wide range of behavioral models can be constructed on the basis of a given set of stock-flow accounting relations. Rather than constructing a fully specified behavioral model, this chapter focuses on a sequence of stock-flow accounting relationships. This allows for consideration of both the problems of modeling financial development - which is here captured through a series of modification to the set of stock-flow relationships - and of the potential for interesting behaviors that are problematic to capture in a fully specified algebraic model.

Returning to the matrix, the zero totals that enforce stock-flow consistency allow for one equation to be obtained from each row and 
column of the system. In the matrix shown above, the rows are trivial and can thus be omitted, giving the following system of equations. It should be noted that this system of equations is over-determined: any one equation in the system is implied by the other three.

$$
\begin{gathered}
W+r_{D} \cdot D_{(-1)}=C+\Delta D \\
C+I=W+r_{L} \cdot L_{(-1)} \\
I=\Delta L \\
\Delta D+r_{L} \cdot L_{(-1)}=\Delta L+r_{D} \cdot D_{(-1)}
\end{gathered}
$$

(See Table 9.1 for definitions of terms.)

This system bears at least a passing resemblance to a classical system of perfect competition - firms do not make any profits so all revenue is returned to households in the form of wages or interest payments. The system differs from a classical model, however, in the fact that no restrictions are imposed on the division of household income between these two flows. In particular, there is no requirement that the marginal productivity of factors of production determines the distribution of household incomes between interest and wage incomes. ${ }^{1}$

The assumption of zero entrepreneurial profits means that firms have only one option for the financing of investment - to increase their financial liabilities by obtaining fresh bank loans. In any period, the total spent on investment will be exactly the same as the net volume of new loans extended by the banking system - thus the total outstanding stock of bank loans will at any point in time equal the total spent on investment up until that point in time.

An entry is included in the matrix for bank profits. This allows for the possible existence of a margin between the rates of interest on bank loans and deposits. However, before examining the implications of the inclusion of banking profits in the model, we consider the simpler case in which banks are assumed to operate costlessly and without profits. This assumption requires that lending and deposit rates must be equal and therefore - if we put aside the possibility of non-performing loans for the time being - that the total volume of loans outstanding must, at any given point in time, equal the total volume of deposits held by households. The volume of deposits will, in the absence of bank profits, therefore also be equal to the total amount spent on investment up until that point. 


\section{PROOF}

If the system were constrained to operate according to marginalist principles, in any given period banks would lend to firms up until the point at which the expected returns on new investment were equal to the rate of interest on loans. This rate of interest would also be that which was just enough to bring forth the quantity of additional deposits needed to finance this additional investment. This is the standard neoclassical view in which 'deposits finance investment.'

The alternative view is that in which bank lending leads deposits. This version originates with Withers (1920), and is subsequently found in both Keynes (1936, chapter 7) and Hayek (1933) and is emphasized by post-Keynesians such as Chick (1986). In this version of the story, economic expansion is led by the decisions of banks and firms. Banks extend loans to the firms sector which invests, using the additional deposits created by the banking system to purchase capital goods from other firms. Receipts for firms are increased by the extra spending, and, in the current model, must therefore accrue as additional wages to households.

Any successful decision to undertake investment by firms will thus result in an increase in the level of deposits held by households as the financial counterpart to saving, as well as expanding the banks' balance sheet. This will then give rise to increased claims on future output in the form of deposit interest. Additional interest payable by firms will be offset by additional interest received on deposits (Toporowski, 2010). But these will be held by households since, by assumption here, firms have no net liquidity or saving. If the investment undertaken increases output, this will be realized through these interest payments as well as potentially lower prices or higher wages. Conversely, if investment is unsuccessful, households will have claims on output in the form of interest payments that firms are unable to meet unless wages are lowered or prices increased.

The preceding discussion highlights some of the potential pitfalls of reasoning in terms of systems of money flows. All of the equations that can be derived from the matrix are ex post identities. One must be extremely careful about the hazards of introducing implicit assumptions about causation into any conclusions drawn about the workings of the system. For example, the previous discussion demonstrated that, with all other entries in the matrix held constant and assuming zero banking profits, in order to have an increased level of spending on investment, there must be an equivalent increase in the level of loans and deposits in the system. This is a very different proposition to the statement that firms are able to automatically increase the level of investment, and therefore output, as long as they are able to gain access to bank loans. The identities of the matrix are equally compatible with the reverse causation: 
because a higher level of household deposits requires higher investment, the system could be read as showing that higher household saving will result in higher investment. This, of course, is the view that was refuted by Keynes in his 'paradox of thrift'. The key point is that the intentions of units at the micro level do not necessarily translate into the equivalent intersectoral flows at the macro level. The transactions matrix can only illustrate at the macro level the various potential logical outcomes of the flow system, regardless of whether these outcomes are compatible with the intentions and expectations of the agents that give rise to them.

Before introducing the first modification to the matrix, let us consider the implications of dropping the assumption that banks make zero profits. If a margin between lending and deposit rates is introduced, while retaining the assumption that the banking system operates with no costs such as wages, the only option is for the rate of accumulation of loans and deposits to diverge by an equal rate. Thus, if the rate of interest set on loans is above that set on deposits, the volume of loans outstanding will expand faster than the volume of household deposits. The net worth of the banking system will thus increase - assets are expanding faster than liabilities. A process of this sort will result in households 'owning' less than the total capital stock, as the volume of deposits held by households will be less than the total spent on investment. A positive spread between deposit and lending rates could also be used as a strategy by the banking system in an attempt to avoid crisis if firms are unable to meet their interest payments and consequently default on their loans - leaving banks with liabilities they cannot meet in the form of deposit interest.

There is one final possibility allowable by the current configuration of the matrix: that the rate of deposit interest is set above the loan rate. Consider the case in which the entire firms sector has defaulted on its debts, and no further loans are being issued: $\Delta L=r_{L} \cdot L_{(-1)}=0$. Firms then have no outgoings other than wages and no receipts other than consumption spending, meaning these two flows must be equal. Banks could then continue to pay their interest obligations by continuing to credit household deposits with additional deposits. A situation of this type is clearly not sustainable indefinitely since it would require the banking sector to issue to each other assets to correspond to the growing deposits of households.

\subsection{Profits in the firms sector}

If we remove the assumption that the profits of the firms sector are zero, as shown in Table 9.2, it becomes possible for firms to be in a position in 


\section{PROOF}

Jan Toporowski and Jo Michell

179

Table 9.2 Retained earnings - not all receipts 'recycled' through the banking sector

\begin{tabular}{|c|c|c|c|c|c|}
\hline & Households & Firms (cur) & Firms (cap) & Banks & Total \\
\hline Consumption & $-C$ & $+C$ & & & 0 \\
\hline Investment & & $+I$ & $-I$ & & 0 \\
\hline$G D P$ & & {$[Y]$} & & & \\
\hline Wages & $+W$ & $-W$ & & & 0 \\
\hline Profits & & $-S_{f}$ & $+S_{f}$ & & 0 \\
\hline Deposit interest & $+r_{D} \cdot D_{(-1)}$ & & & $-r_{D} \cdot D_{(-1)}$ & 0 \\
\hline Loan interest & & $-r_{L} \cdot L_{(-1)}$ & & $+r_{L} \cdot L_{(-1)}$ & 0 \\
\hline Net fin. balance & {$\left[S_{h}\right]$} & {$[0]$} & {$\left[S_{f}-I\right]$} & {$[0]$} & \\
\hline Change in Deposits & $-\Delta D$ & & & $+\Delta D$ & 0 \\
\hline Change in Loans & & & $+\Delta L$ & $-\Delta L$ & 0 \\
\hline Total & 0 & 0 & 0 & 0 & 0 \\
\hline
\end{tabular}

which revenues are not all returned to households in the form of wages and interest payments. ${ }^{2}$ This reduces the firms sector's reliance on bank loans to finance investment. By using earnings to finance investment, firms are able to 'short-circuit' the banking system thus avoiding the need to pay interest on loans taken out to finance investment. This may then have second-round effects in that the increase in net revenues in future periods may also be diverted to further investment rather than spent on consumption by the household sector.

How can we get from a situation such as that shown in the previous matrix, in which all income is returned to households in the form of wages and interest, to a situation in which firms are able to 'recycle' revenues back into investment? The only way that firms can 'directly' divert a portion of current income to investment - rather than this occurring via the banking system - is for outgoings to be reduced relative to receipts. In the current configuration of the model this implies a reduction in either wages or interest payments relative to total income. Viewed in neoclassical terms, this implies that the model has departed from a world of perfect competition, with firms able to exert some degree of monopoly power, allowing for a mark-up between costs and prices.

In the previous matrix, the possibility of 'forced saving' existed through banks extending loans to firms. Investment could thus take place and would result in deposits accruing to households as the counterpart to loan-financed investment. With the possibility of a markup on prices over costs, firm's profits become another mechanism by 
which saving, and thus investment, can be 'forced' into the system. The advantage to firms in this case is that new investment can now take place without a corresponding increase in liabilities on their balance sheets. In the extreme case, in which all new investment is financed out of profits, all investment results in an increase in net worth for the firms sector with no increase in liabilities.

The difference between this case and the previous one in which all new investment is financed through bank lending occurs purely in the financial sector - exactly the same level of consumption and increase in the capital stock could take place in each of the two scenarios. Adjustments of the price of consumption goods relative to wages thus allows for a range of financial sector outcomes that are compatible with a single set of real-sector flow magnitudes.

This matrix may be utilized to shed some light on the well-known Kalecki-Steindl profit reflux equation. This can be obtained by extracting the net financial balance row from the matrix, and rearranging to give

$$
S_{f}=I-S_{h}
$$

The usual interpretation of this identity is that an increase in household saving - or the failure of it to decrease in the face of a drop in investment - will reduce the retained profits of firms. Furthermore, the only variable over which firms have direct influence is investment. Thus, investment is seen as the source of profits at the aggregate level, with a higher level of investment resulting in a higher level of firm's profits, and thus an increase in the financial assets of firms: 'If additional investment is financed by bank credit, the spending of the amounts in question will cause equal amounts of saved profits to accumulate as bank deposits (Kalecki, 1954, p. 50).

In this configuration of the model, another possibility is shown. If firms are assumed at this stage not to hold financial assets such as bank deposits, firms' net income after interest and dividends must be used to pay off the loans used to finance investment. Thus, if profits increase to a level greater than the amount spent on investment, the balance sheet of the banking system will contract as repayment of debts cancels both deposits and loans. The contraction of household deposits is a necessary counterpart to the negative financial balance that must be run by the sector in order that firm profits can exceed investment. Conversely, a lower level of profit implies higher household saving in the form of bank deposits, and hence greater firm indebtedness. Without the inclusion of a government or external sector, the worst possible position 


\section{PROOF}

Jan Toporowski and Jo Michell

181

for the firms sector is just to break even: $S_{f}=0$ and $S_{h}=I$. By expanding the model to include a government sector and external sector, and allowing firms to borrow to cover operating losses as well as investment, the full version of the Kalecki-Steindl equation ${ }^{3}$ could be incorporated. The inclusion of these sectors results in the possibility of the firms sector operating at a loss and hence being forced to incur increased debt if the government surplus and current account deficit combine with household saving to exceed investment.

\subsection{Excess capital}

The next modification we make to the flow model is to allow the holding of bank deposits by firms, as shown in Table 9.3. With this change comes a much broader range of possible ways in which the configuration of assets and liabilities in the system can evolve. By introducing the possibility that firms may choose to hold financial assets rather than engage in productive investment, the potential for overcapitalization of the firms sector arises.

Overcapitalization refers to the 'holding of financial liabilities in excess of those needed to undertake production' (Toporowski, 2008). This is obviously not possible in the previous stages of the model in which the only uses of funds available to firms are the payment of wages, and investment in capital goods. This changes once firms have the opportunity to accumulate funds in the form of bank deposits - as long as a firm has both financial assets and liabilities on its balance sheet it is, by the above definition, holding excess capital.

Table 9.3 Simple overcapitalization: excess capital held in the form of deposits

\begin{tabular}{lllllc}
\hline & Households & Firms (cur) & Firms (cap) & Banks & Total \\
\hline Consumption & $-C$ & $+C$ & & & 0 \\
Investment & & $+I$ & $-I$ & & 0 \\
$G D P$ & {$[Y]$} & & & \\
Wages & $+W$ & $-W$ & & & 0 \\
Profits & & $-S_{f}$ & $+S_{f}$ & $-r_{D} \cdot D_{(-1)}$ & 0 \\
Deposit interest & $+r_{D} \cdot D_{h(-1)}$ & $+r_{D} \cdot D_{f(-1)}$ & & $+r_{L} \cdot L_{(-1)}$ & 0 \\
Loan interest & & $-r_{L} \cdot L_{(-1)}$ & & {$[0]$} & \\
Net fin. balance & {$\left[S_{h}\right]$} & {$[0]$} & {$\left[S_{f}-I\right]$} & $+\Delta D$ & 0 \\
Change in Deposits & $-\Delta D_{h}$ & & $-\Delta D_{f}$ & $-\Delta L$ & 0 \\
Change in Loans & & & $+\Delta L$ & $-\Delta L$ \\
Total & 0 & 0 & 0 & 0 & 0 \\
\hline
\end{tabular}




\section{PROOF}

What are the implications of the holdings of excess capital by firms? This depends in part on the way in which this capital is accumulated. It is argued by (Toporowski, 2008, p. 8) that

...it may be supposed that since saving equals investment, it is not possible for firms to hold excess capital, except as net debt issued by either households, the government, or the foreign sector. This is true if it is assumed that all production is, and has only ever been, undertaken by capitalistic firms.

In this view, if we take as given that our model represents a system of capitalistic production, that is production using capital equipment, the only sector that could issue this net debt is the household sector. Thus, as a consequence of the household sector consuming in excess of its income, it would emit liabilities the counterpart of which would be financial assets held by the firms sector. The problem with this is that in order for the firms sector to be overcapitalized, it must have issued financial liabilities in order to finance its purchase of financial assets. Who then will hold these financial liabilities as assets? If these assets are held by households, these then would then offset household liabilities, resulting in a neutral net financial position, rather than a position of net issuance of debt.

There is another alternative suggested by the current configuration of the model. The possibility of the household sector being in a negative net financial position is excluded by the assumption that households are unable to issue any financial liabilities. However, the firms sector as a whole may now hold excess capital simply by having both loans and deposits on its balance sheet. How would such a situation arise? Consider the two following extreme cases in which the total stock of deposits that are the counterpart to loan-financed investment end up on respectively on the balance sheets of households, in the first instance, and firms in the second.

The standard 'sectoral deficits' story, in which a surplus in the household sector finances investment in the corporate sector via the banking system, is as follows: banks create loans and deposits simultaneously by crediting the accounts of firms at the same time as issuing new loans. This money is used to finance new investment. The additional receipts for firms from selling capital goods, over and above that received as the result of household spending on consumption, is returned to households in the form of wages, by transferring deposits from the accounts of firms to the accounts of households. As wages total an amount 


\section{PROOF}

Jan Toporowski and Jo Michell

183

greater than that spent on consumption, the household sector has unspent deposits at the end of period equal to the amount spent on investment, and to the volume of new loans created. Thus, each period, $S_{h}=\Delta D_{h}=\Delta L$ and $S_{f}=0$.

This is entirely compatible with the classical theory: in subsequent periods, the additional output that results from new investment will accrue as interest, via the banking system, to the household sector, allowing for increased consumption. Neoclassical theory assumes that all prices, and the rate of interest, will adjust such that the amount of investment undertaken by firms will be of exactly the amount that will give a return equal to the amount of saving desired by households.

Consider now the alternative wherein instead of firms paying out in wages (and interest, in periods other than the initial one) an amount equal to total receipts, they are able to pay wages and interest such that $C=W+r_{D} \cdot D_{h(-1)}$ - wages and interest payments on deposits exactly cover the amount spent on consumption. If households were to spend the same amount on consumption as in the previous example, they will now exhaust all of their income and see no change in the level of deposits held. Firms, on the other hand, will have an excess of income over outgoings equivalent to the amount spent on investment, which will be returned as deposits.

Note that the real sector outcome in each of the two scenarios is identical: a proportion $I /(C+I)$ of total output is directed to investment, which is by definition equal to saving. The differences between the two cases lie in the configuration of financial assets and liabilities at the end of the period. This 'accounting' difference is significant, as the owners of deposits will receive interest payments on their 'lending', while issuers of liabilities in the form of loans must pay interest.

In the first of the two cases, the final configuration of deposits and liabilities represents net lending from the household sector to the firms sector. The investment undertaken by firms must thus generate increased output in future periods of an amount great enough to cover the interest liabilities resulting from this lending. In the second case of 'overcapitalization', there has been no intersectoral net lending - the increase in deposits held by the firms sector is equal to the increase in loans it holds. Thus, the cost of borrowing to the firms sector as a whole is in this case proportional to the margin between the loan and deposit rates of interest, rather than the absolute value of the loan rate of interest, as is usually assumed in discussion of the effect on investment of changes in the rate of interest. (Toporowski, 2010). The per-period cost 
of additional excess capital financed from bank lending is thus the following:

$$
\Delta L\left(r_{L}-r_{D}\right)
$$

Toporowski describes the situation where investment continues to be financed as in this way, with further investment in subsequent periods also financed out of bank lending:

What happens if firms finance their investment entirely through debt? After a number of years, firms will end up with a stock of debt that is exactly equal to the sum of their expenditures on capital formation over those years. In addition... all firms will have deposited into their banks retained profits exactly equal to the amount that the firms have spent on capital formation. The banking system will have deposit liabilities to firms that exactly equal to the amount that the banks have advanced to firms to pay for that capital formation. The firms sector as a whole will have debts equal to the capital equipment that has been purchased over the years. But those debts will be exactly hedged (for the capitalist firms as a whole) by cash deposits in the banking system. If the financing structure of all firms corresponds to some representative 'average' firms, then the financing of every firm will be perfectly hedged with bank deposits. (Toporowski, 2010, pp. 2-3)

There is another possibility: once firms have undertaken investment financed in the way shown in Table 9.3, at the start of the subsequent period the firms sector will be holding deposits equal to the total expenditure in the current period. Firms thus only need to expand the liability side of their balance sheet in subsequent periods if they wish to invest a greater amount than in the current period - or if they wish to increase their level of excess capital. This would be equivalent to a switch to financing through retained profits.

In either the case of 'complete overcapitalization', in which firms end up with a stock of debt and deposits matched by the total spent on investment, or the case of 'marginal overcapitalization', in which the stock of debt is incrementally increased as desired investment exceeds the stock of retained profits, the rate of interest - and thus the balance sheet of the firms sector - behave in a quite different way to that of standard marginalist theory. As previously noted, it is the margin between the lending and deposit rates faced by firms that represents 


\section{PROOF}

Jan Toporowski and Jo Michell

185

the cost of overcapitalization - and in this example, real investment. ${ }^{4}$ Thus, the standard view of the relationship between the investment decisions of firms and the conduct of interest rate policy by the central bank - higher bank rate will, ceteris paribus, induce lower investment may not hold unless a higher bank rate in some way results in a wider spread between lending and deposit rates. ${ }^{5}$ Similarly, if the central bank were to operate in such a way as to attempt to restrict the availability of loans through quantitative measures, textbook theory would argue that the reduced availability of credit and the associated interest rate rises should ensure that only more potentially profitable investments would be undertaken. However, if the spread between lending and deposit rates does not widen, the cost of investment will not rise. The distribution of credit among firms may in this case be determined by factors other than expected returns on investment. In practice, credit restrictions would increase the margin between deposit and lending rates.

If we assume for the time being that all deposits will be held by firms and not households, what factors will determine the level of overcapitalization of firms - what proportion of the total spent on investment will be held as deposits funded by equivalent outstanding loans? ${ }^{6}$ Liquidity preference due to uncertainty about the future is one obvious answer to this question. Another possibility is that the banking system may in some way induce the firms sector to hold excess liquidity, through monopoly power over firms or by forcing firms to borrow for longer periods than required.

It is at this point that some limitations of the accounting identities come into focus. Firstly, just from inspection of the transactions matrix, there does not appear to be any direct connection between real investment and the financial assets and liabilities of the firms sector. Given any initial set of valid values for the matrix, spending on investment can be increased by any amount - without violating any of the identities implied by the matrix - as long as profits are increased by the same amount. However, we know that an increase in investment cannot take place without a prior expansion of lending by banks to the firms sector - even if all this additional spending remains within the firms sector as retained profits. It is, of course, possible that firms will borrow from banks to undertake investment, and then in the same period use the retained earnings to repay the bank loans, thus resulting in a set of net transactions that show only an increase in profits and investment.

A second issue, and one that to which we will return later, is the problem of the level of disaggregation in the model. By examining the money flows into and out of a number of sectors of the economy, the dynamics 
of changes within each of those sectors is obscured from view. There are many ways in which this could mask important economic behavior. One possibility relates to variations in the financing structure of businesses within the firms sector - although in the overcapitalization case it appears that the firms sector as a whole is fully hedged against its liabilities as deposits circulate within the sector as a whole and do not end up in the hands of households, it is possible that a redistribution of assets and liabilities is taking place within the sector. For example, it is possible that larger firms are more profitable than smaller firms, due to monopoly pricing for example. This would mean smaller firms requiring a higher level of loan finance to undertake investment, while large firms are able to invest using retained earnings. In this case, some part of the deposits that are the counterpart to the loans used to finance investment end up not on the balance sheets of the small firms that took out the loans, but on those of the larger monopolist firms. This type of effect could be incorporated into the model by splitting the firms sector into large and small firms. However, each additional division of the system in this way increases, by a significant margin, the complexity of any fully specified behavioural model built upon the matrix. Furthermore, the intrasectoral flow dynamics may be more subtle than can be captured by a simple two-way division: there may a gradation of financing structures as firms increase in size, or different financing structures depending on the type of industry in which the firm operates. In particular, financing of investment by means of retained profits would result in increases in fixed capital assets, but with no change in the loan liabilities of firms. There would be an increase or decrease in wage revenue and profits depending on whether there was an increase or decrease in investment. But there would be no change in the financial balances of the firms sector as a whole.

\subsection{Equity issuance}

The final development that will be discussed is the inclusion of equities as an asset class. In most models, equity issuance is seen as an alternative way for firms to obtain access to investment funds in the form of the savings of other sectors - primarily the household sector - often channeled via institutional intermediaries such as pension funds. The issuance of equity allows for the expansion of investment without the concomitant expansion of debt liabilities.

Much of the recent literature on 'financialization' tends to focus on issues of 'shareholder value' -- models are constructed which examine 


\section{PROOF}

Jan Toporowski and Jo Michell

187

the effects on growth of the way in which firms allocate earnings between real investment and dividend payouts, with increasing shareholder power resulting in a focus on short-term profits at the expense of longer-term investment. ${ }^{7}$

It is argued here that there are important aspects of firm behavior that are overlooked in these models. These relate to both firms' decisions on the structure of liabilities issued, and to the decisions of firms on the allocation of funds between real and financial assets. It is argued by Toporowski (2000) that, rather than issuing equity for the purposes of financing new investment in real assets, those firms that have access to the capital markets use them to maintain internal liquidity by raising cash against previous investment projects. Equity issuance is thus used as a mechanism to maintain a state of overcapitalization following the depletion of internal funds by spending on investment projects. Furthermore, when faced with a situation of rising prices in the equities markets, it may become profitable for overcapitalized firms to allocate excess capital to financial assets in preference to engaging in real investment.

Table 9.4 shows the transactions matrix used in the previous examples, modified to include a new class of financial assets in the form of equities. The number of equities issued is represented by $e$, the price is represented by $p$, and the dividend payout per-share by $d$. Two additional financial flows are thus shown in the transactions matrix: the

Table 9.4 Speculative overcapitalization: firms hold excess capital as financial securities

\begin{tabular}{lllllc}
\hline & Households & Firms (cur) & Firms (cap) & Banks & Total \\
\hline Consumption & $-C$ & $+C$ & & & 0 \\
Investment & & $+I$ & $-I$ & & 0 \\
$G D P$ & {$[Y]$} & & & \\
Wages & $+W$ & $-W$ & & & 0 \\
Profits & & $-S_{f}$ & $+S_{f}$ & $-r_{D} \cdot D_{(-1)}$ & 0 \\
Deposit interest & $+r_{D} \cdot D_{h(-1)}$ & $+r_{D} \cdot D_{f(-1)}$ & & $+r_{L} \cdot L_{(-1)}$ & 0 \\
Loan interest & & $-r_{L} \cdot L_{(-1)}$ & & & 0 \\
Dividend payments & $+d \cdot e_{h(-1)}$ & $-d \cdot e_{h(-1)}$ & & {$[0]$} & \\
Net fin. balance & {$\left[S_{h}\right]$} & {$[0]$} & {$\left[S_{f}-I\right]$} & $+\Delta D$ & 0 \\
Change in Deposits & $-\Delta D_{h}$ & & $-\Delta D_{f}$ & $+\Delta L$ & 0 \\
Change in Loans & & & $+\Delta L$ & & 0 \\
Change in Equity & $-\Delta e_{h} \cdot p_{e}$ & & $+\Delta e_{h} \cdot p_{e}$ & & \\
$\quad$ issuance & & 0 & 0 & 0 & 0 \\
Total & 0 & 0 & & &
\end{tabular}


change in equity holdings by the household sector, and the dividend payout based on holdings in the previous period.

It was argued in the previous section that the cost to the firms sector of holding liquidity in the form of deposits depends on the level of profitability of firms, or equivalently the level of household saving - if firms do not turn a profit then any liquidity held by the firms sector must be borrowed from the banking sector, with the margin between deposit and lending rates as the cost of this liquidity. Note that this liquidity is not borrowed from the household sector - both the loans and deposits that are 'created' with new bank lending appear on the balance sheets of firms.

Once firms gain access to the capital markets, the issuance of equity provides an alternative to debt as a way of maintaining a state of overcapitalization. By issuing fresh equity, firms can replenish their stocks of liquidity, using the returns on previous investment to fund the dividend payments that they become liable for with the issuance of new stock. The issue of new equity, purchased by households, transfers bank deposits from households (or other firms) to firms issuing equity.

The introduction of equities as an asset class also allows for the consideration of capital gains - something that presents problems in the context of a flow-of-funds analysis, as the prices of equities can change without resulting in any intersectoral flows. ${ }^{8}$

Broadly speaking, there are two reasons why the prices of equities would change in the absence of any new issuance of shares. The first is the appearance of some new piece of information on the prospective returns from real investment. If there is a rise in the expected level of dividend payments, money flows will arise as a result of funds being reallocated between bank deposits and securities in the portfolios of households. Any rise in retained profits, in the form of increased firms' bank deposits, would reinforce the expectation of a higher dividend and increase the potential value of equity. The second possibility arises from the fact that, once a rise in the prices of shares has taken place, the expectation of further rises in share prices and thus the prospect of capital gains for the owners of equity may cause further inflows into these assets. In turn, this inflow of funds causes prices to rise, validating the judgment of those astute enough to have seen them coming.

In the case of equity-financed investment, there would be a reduction in the bank deposits of the households (or firms) buying new equity. However, there would then be a corresponding increase in the bank deposits of firms as a result of the investment expenditure. Accordingly, on the balance sheet of the firms sector, the new equity liabilities would 


\section{PROOF}

be balanced by bank deposits. In addition, of course, firm balance sheets would also show further increases on the asset side in the form of new fixed capital equipment.

As always, in a closed flow-of-funds system, a flow into a class of assets cannot happen in isolation - all flows must originate somewhere. If all equity is initially held by households, how can household buying of equity in response to some exogenous event cause a rise in share prices? Again the problem of aggregation in a stock-flow model shows itself - what is required is that some subdivision of the household sector is willing to purchase equities at a price higher than that which was paid by the current holders. There is thus a redistribution of the ownership of equity within the household sector, accompanied by a rise in the prices of shares. There must also be a corresponding intra-sectoral flow in the opposite direction representing the payment for the newly purchased shares. This is likely to take the form of a redistribution of bank deposits to offset the change in equity holdings.

If it is assumed that all purchases of equity in the secondary markets by households are undertaken using bank deposits as payment, there is thus a limit to the extent to which price inflation in the capital markets can take place, set by the total stock of deposits in the household system - eventually the distribution of equities and deposits within the household sector will take on a configuration such that no further redistribution and price rises are possible, without further deposits becoming available to the household sector to use as means of payment.

Although, at first glance, the impression given by the matrix is that households are the only sector which holds equities, we may also consider the situation wherein newly issued equities are purchased by other firms within the corporate sector - in this situation there will be a reallocation of deposits within the firms sector and an increase in both the holding and issuance of equities within the sector. However, none of these changes will result in an intersectoral flow of funds, and thus an entry on the transactions matrix. A change in the relative wealth of the household and firms sectors is possible without any entry appearing on the flow matrix, in both the case of a redistribution of equities within the household sector and within the firms sector. The only changes that will be visible in the current schema are those which involve a change in the total holdings of equities by households.

What are the consequences of the holding of equities by the firms sector? In a setting of rising prices in equity markets, overcapitalized firms face a trade-off in how to allocate excess capital between real investment, deposits and equities - it is possible that the expected capital 
gains on equities will be great enough to offset the cost of overcapitalization (Toporowski, 2008). The conditions under which this will be the case depends initially on the historical profitability of firms, that is to what extent the financial assets corresponding to previous investment have accrued on the balance sheets of households or firms, and upon whether equity was initially purchased by households or firms. We can examine each combination of cases in turn.

Consider first the case wherein firms collectively have no retained profits, so that the deposits that correspond to real saving and investment are all held in the household sector, so $S_{h}=I=D_{h}=L$. Now, as argued before, if they wish to overcapitalize, the cost to firms will be the margin between lending and deposit rates, as any deposits held by the firms sector will have to be obtained through bank lending. If firms now begin to issue equity as a way of raising further capital, these equities may be purchased either by households, or by other firms.

Again the two 'edge cases' are of interest: if all equity is bought by households, the result is a flow of deposits from households to firms as payment. Firms are thus able to increase the liquidity of their balance sheets without recourse to further bank borrowing. The cost of this excess capital is now the margin between the dividends paid out on the equity held by households, and the rate of interest paid on the deposits of firms. Now consider a further development whereby at some subsequent point, in response to a rise in equity prices, firms choose to purchase stocks on the assumption that they will make capital gains. If all equity is bought back from the household sector, the balance sheets of all sectors are identical to how they were before equity was issued, except that some subset of the firms sector now holds the equity of some other subset of the firms sector. The cost to the firms sector of this form of overcapitalization is nil at the aggregate level - all dividends paid out remain within the firms sector. The final balance sheet position of each of the three sectors in this case is shown in Table 9.5 .

Alternatively, as equity is initially issued, firms may purchase it directly from each other. In the case under discussion where all deposits are held by households as the counterpart to loan-funded investment, firms will only be able to purchase equities by obtaining fresh liquidity in the form of further loans from the banking system. The deposits created as the counterpart to these loans will remain within the firms sector, as firms purchase shares from one another. Not all firms will necessarily increase their liabilities - some firms may only issue fresh equity, as a way of increasing liquidity or paying back previous loans, 


\section{PROOF}

Jan Toporowski and Jo Michell

191

Table 9.5 Sectoral balance sheet: saving in household sector, equity initially bought by households

\begin{tabular}{llll}
\hline & Households & Firms & Bank \\
\hline Physical Capital & & $+K$ & \\
Deposits & $+D$ & & $-D$ \\
Loans & & $-L$ & $+L$ \\
Equities & & $-e \cdot p$ & \\
Total (Net Worth) & $D$ & $+e \cdot p$ & \\
\hline
\end{tabular}

while some take on fresh debt in order to buy equities. Some firms may both issue new equity and purchase stocks, meaning they are able to hold equities without incurring further debt. The total level of debt in the firms sector will thus depend upon the extent to which firms that issue new equity choose to use newly available liquidity to pay off loans. In the case that no loans are paid off, there will have been an increase in both loans and deposits in the firms sector by exactly to the amount that was raised by issuing equity. The cost to the firms sector as a whole of this new asset and liability structure will thus be the amount raised by equity issuance multiplied by the margin between deposit and lending rates, $e \cdot p \cdot\left(r_{L}-r_{D}\right)$. The final sectoral balance sheets for this case are shown in Table 9.6. In this balance sheet, those magnitudes greater than the total amount spent on real investment are marked with an asterisk: for example, the volume of loans outstanding is greater than the amount spent on real investment in this case, since firms have used loans both to finance real investment and to purchase equities.

Now consider a third case in which the financial saving that is the counterpart to real investment has accrued to firms as profits, and the household sector holds no financial assets. In this case, if firms begin to issue equity, it is not possible for the household sector to purchase the shares as they hold no savings. Thus the only possibility is for firms to buy the stock of other firms. As this takes place, there is once again no intersectoral flow of funds since the deposits used by firms to buy stock are transferred to other firms. The additional costs to the firms sector as a whole in holding additional capital in the form of equities is thus once again zero in this case. The balance sheet for this case is shown in Table 9.7.

There are thus three potential 'edge case' configurations of firm overcapitalization through the ownership of equity: two that originate with the situation in which real investment was originally financed by 


\section{PROOF}

Table 9.6 Sectoral balance sheet: saving in household sector, equity initially bought by firms

\begin{tabular}{llll}
\hline & Households & Firms & Bank \\
\hline Physical Capital & & $+K$ & \\
Deposits & $+D_{h}$ & $+D_{f}$ & $-D^{*}$ \\
Loans & & $-L^{*}$ & $+L^{*}$ \\
Equities & & $-e \cdot p$ & \\
Total (Net Worth) & $D_{h}$ & $+e \cdot p$ & \\
\hline
\end{tabular}

Table 9.7 Sectoral balance sheet: saving in firm sector, equity initially bought by firms

\begin{tabular}{lcll}
\hline & Households & Firms & Bank \\
\hline Physical Capital & & $+K$ & \\
Deposits & $+D$ & $-D$ \\
Loans & & $-L$ & $+L$ \\
Equities & & $-e \cdot p$ & \\
Total (Net Worth) & 0 & $K$ & 0 \\
\hline
\end{tabular}

a sectoral surplus in the household sector, and one in which retained earnings allowed firms to invest without incurring any net financial liabilities. The balance sheets of these three possible cases are shown in Tables 9.5, 9.6 and 9.7. In each of the three cases, the combination of the net worth of each sector, and the cost to the firms sector of holding excess capital in the form of equity, is different.

There exists finally the possibility of a process of capital market inflation (Toporowski 2000, Part I). This would correspond to an increase in the value of equity held by households, through insurance and pension fund intermediaries. In the firms sector, the increase in equity liabilities would be matched by a reduction in firms' borrowing from banks and/or an increase in bank deposits. In the case of an increase in bank deposits, this would correspond to the case of firm overcapitalization described above. Reduced bank borrowing by firms, or an increase in firms' bank deposits, means an increase in banks' overall net liabilities to the firms sector. In the balance sheet of the banking system, the increase in net liabilities to firms is then balanced by higher borrowing of households, which could be secured against their equity holdings, but could just as easily be secured against other assets, such as residential property. 


\section{PROOF}

Jan Toporowski and Jo Michell

193

\subsection{Concluding remarks}

This chapter has examined, under the conditions imposed by adhering to stock-flow consistency, the possible evolution of a highly simplified, idealized system of sectoral financial accounts. The focus has been upon financial development, and, specifically, the changing ways in which firms finance their investment as financial development progresses. A stylized progression from funding investment via bank lending, through to financing from retained earnings and finally to equity issuance, overcapitalization and financial speculation are introduced.

The various possible balance sheet structures that arise as a consequence of different paths of the financing of investment in real assets and speculative financial positions result in differing levels of financial fragility for the firms sector. In particular, the Kalecki-Steindl result that household saving increases firms' indebtedness, and hence financial fragility, is demonstrated in a simple stock-flow framework. However, the consequences of overcapitalization in particular depend on subsequent movements in capital markets and firms' investment decisions. For example, firms may borrow to buy equities within the firms sector, pushing up the price of equities, resulting in increased liquidity in the firms sector as well as higher balance-sheet wealth. This in turn may spur investment, increasing firm profitability, thus ex post validating the increase in share prices (Minsky, 1986 [2008], Chapter 8). Alternatively, if firms push up share prices through redistributing deposits among themselves in preference to real investment, taking on additional loan liabilities in the process - as in Table 9.6 - the potential exists for crisis when interest liabilities cannot be covered from operating profits and capital gains. The liquidity of capital markets is thus vital to the ability of firms to realize capital gains, while the internal liquidity of firms may be an important determinant of their ability to gain access to further bank lending.

Although the development of the financial system, and thus of the financing structures of firms within that system, is presented here as a linear process, in a real economic system the evolution of firms' balance sheets will be conditioned both by the level of overall financial development, and by the current position in the business cycle. It is this cyclical perspective in particular that is largely missing in the current crop of 'stock-flow consistent' models. Minsky's ([1975] 2008) critique of Chapter 17 of the General Theory was that at the crucial point in Keynes' analysis, he reverted to a marginalist conception of investment - rather than the cyclical perspective that can be detected 
in the rest of the book. This critique is also applicable in some respects to these stock-flow models. Although they are based around the balance sheets of the various sectors of the economy, and incorporate detailed financial structure - thus considering explicitly the evolution of assets and liabilities and their associated money flows - the method by which the models are employed to draw conclusions about the workings of the economic system is in fact very close to that of neoclassical dynamicstochastic general equilibrium models, such as that of Woodford (2003). This method utilized is to first locate the steady-state equilibrium of the model, and then use computer simulations to examine the behaviour of the system when some exogenous shock is applied to the system - with the system eventually returning to equilibrium.

A final conclusion may therefore be that stock-flow consistent models need to incorporate more explicitly the type of financially driven cyclical behavior, emphasized by Minsky, and development as a process of disruption to the normal circular flow as described by Schumpeter:

... development in our sense is a distinct phenomenon, entirely foreign to what may be observed in the circular flow or in the tendency towards equilibrium. It is the spontaneous and discontinuous change in the channels of the flow, disturbance of equilibrium, which forever alters and displaces the equilibrium state previously existing. (Schumpeter 1934)

\section{Notes}

1. The system is also has a similarity to the Wicksell's (1936) 'Pure Credit Economy', although in Wicksell's system the finance for investment is provided not by surpluses in the household sector but by 'capitalists'. This finance is lent via the banking system to a distinct class of 'entrepreneurs' who use these borrowed funds to finance investment in working capital.

2. We have also reintroduced the assumption that banks make zero profit, which allows us to simplify the matrix by removing the distinction between the current and capital accounts of the banking system.

3. $S_{f}=I-S_{h}+(G-T)+(X-M)$.

4. We have assumed zero profits in the banking system for the sake of simplicity, which rules out a spread between lending and deposit rates. However, if we were to instead assume that all banking sector profits are returned to households, the difference between investment that results in households holding deposits, and investment that results in firms holding deposits is clear: in the former, the cost to firms of investment is $I \cdot r_{L}$, whereas in the latter case it is $I \cdot\left(r_{L}-r_{D}\right)$. 
5. The current model would need to be extended to include a central bank as a separate sector in order to consider the implementation of monetary policy in detail.

6. It is of course possible that the degree of overcapitalization will exceed the level of investment: despite investment spending returning to firms as deposits, firms may borrow more than is required to finance investment, and hold the excess as deposits.

7. For example, Hein (2008), van Treeck (2008), Stockhammer (2004).

8. Godley and Lavoie utilize an explicit 'revaluation matrix' in their models to keep track of the changes that arise due to movements in asset prices.

\section{References}

Chick, V. (1986) 'The Evolution of the Banking System and the Theory of Saving, Investment and Interest,' Economies et Sociétés 3(8-9): 111-26.

Godley, W. and M. Lavoie (2007) Monetary Economics: An Integrated Approach to Credit, Money, Income, Production and Wealth (Basingstoke, UK: Palgrave Macmillan).

Hayek, F.A. (1933 [1966]) Monetary Theory and the Trade Cycle (New York, NY: Augustus M. Kelley).

Hein, E. (2008) “"Financialisation" in a Comparative Static, Stock-flow Consistent Post-Kaleckian Distribution and Growth Model,' Working Paper No. 21 (Düsseldorf, Germany: IMK at the Hans Boeckler Foundation, Macroeconomic Policy Institute).

Kalecki, M. (1954) Theory of Economic Dynamics An Essay on Cyclical and Long-Run Changes in Capitalist Economy (London: George Allen and Unwin).

Keynes, J.M. (1936) The General Theory of Employment, Interest, and Money (London: Macmillan Publishing Company).

Minsky, H.P. (1975 [2008]) John Maynard Keynes (New York: Columbia University Press) republished in D.B. Papadimitriou and L.R. Wray (eds) Hyman P. Minsky's John Maynard Keynes (New York: McGraw-Hill).

Minsky, H.P. (1986 [2008]) Stabilizing an Unstable Economy (New Haven, CT: Yale University Press) republished in D.B. Papadimitriou and L.R. Wray (eds) Hyman P. Minsky's Stabilizing an Unstable Economy (New York: McGraw-Hill).

Schumpeter, J. (1934) The Theory of Economic Development (Cambridge, MA: Harvard University Press).

Stockhammer, E. (2004) 'Financialization and the Slowdown of Accumulation,' Cambridge Journal of Economics 28(5): 719-41.

Toporowski, J. (2000) The End of Finance: The Theory of Capital Market Inflation, Financial Derivatives and Pension Fund Capitalism (London: Routledge).

Toporowski, J. (2001) 'European Destiny and Macroeconomic Responsibility in the Financial Systems of Germany and the UK: A Balance Sheet Approach,' in S. Frowen and F. McHugh (eds) Financial Competition, Risk and Accountability, British and German Experiences (London: Palgrave).

Toporowski, J. (2008) 'Excess Capital and Liquidity Management,' Working Paper No. 549 (Annandale-on-Hudson, NY: Levy Economics Institute of Bard College). 
Toporowski, J. (2010) 'Corporate Liquidity and Financial Fragility,' paper presented at the Boeckler Foundation Macroeconomics Conference, Berlin.

van Treeck, T. (2008) 'A Synthetic, Stock-flow Consistent Macroeconomic Model of "Financialisation",' Cambridge Journal of Economics 33(3): 467-93.

Wicksell, K. (1936) Interest and Prices: A Study of the Causes Regulating the Vale of Money (London, UK: Macmillan).

Withers, H. (1920) The Meaning of Money (New York: E.P. Dutton and Company).

Woodford, M. (2003) Interest and Prices: Foundations of a Theory of Monetary Policy (Princeton, NJ: Princeton University Press). 